\title{
The Perception on the Relation between Religion and Science: A Cross Culture Study in the Malaysian Society
}

\author{
Mohd Arip Kasmo ${ }^{1}$, Bayu Taufiq Possumah ${ }^{2}$, Wan Zulkifli Wan Hassan ${ }^{1}$, Nasruddin Yunos ${ }^{1} \&$ Zulkifli Mohamad \\ ${ }^{1}$ Centre for General Studies, The National University of Malaysia, Malaysia \\ ${ }^{2}$ Institute of Islam Hadhari, The National University of Malaysia, Malaysia \\ Correspondence: Abur Hamdi Usman, Institute of Islam Hadhari, The National University of Malaysia, Selangor, \\ 43600, Malaysia. Tel: 60-166-905-082. E-mail: aburhamdiusman@yahoo.com
}

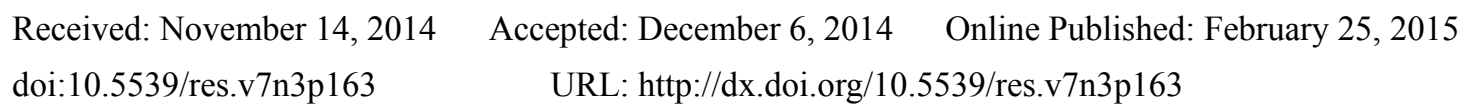

\begin{abstract}
The study reports a research which was conducted on 640 respondents of Malaysian society to know their perception on the relation between science and religion. The study was conducted throughout the country of Malaysia involving male and female respondents from the age of 20 to 50 years from various ethnics and religious backgrounds. The study was conducted by using the questionnaire method in which the respondents were asked to respond to given statements on the relation between science and religion and the importance of religion and science for human being. The booklets of questionnaire were collected to be analysed using the SPSS to obtain the mean response according to the ethnic, religious and academic background. T-test were also conducted if the means responses were significantly different. The findings of the study show that generally the respondents accept that science leads people closer to god. The mean response between the different ethnic group's means was also significant. Moreover, the finding also shows that the respondent accept the importance of religion and science for the well being of the people.
\end{abstract}

Keywords: science, religion, Malaysia, perception

\section{Introduction}

Science has played an important role in shaping the human society since the beginning of human civilisation. The development of scientific knowledge progresses from the time of the ancient Greek until today and it had made great achievements in the last 400 years by expanding human understanding of the world and nature as well as creating a lot of technological inventions which has never been achieved by any civilisation before (Moravcsick, 1988). However, science has also led to human miseries when it is used as a mean of causing maximum destruction in warfare such as the creation of the atomic bomb, chemical bomb, biological warfare and also as a mean of wealth accumulation by the capitalists' world where science is used to maximise the exploitation of the resources leading to rapid depletion of the natural resources, pollution and the global warming (Garaudy, 1982).

One of the importance consequences of science is the weakening of religious belief in the western society. Science which is based on logic is considered to be opposed to religious belief, and such as science progresses religious belief weakened. This belief is considered to be widespread in the developed world such as the Western Europe, the North America, New Zealand and Australia. A society which regards science as oppose to religion will either abandon religion or abandon science because they are considered to be mutually exclusive (Faruqi, 1992).

In the contact of the Muslim society in Malaysia, science had been regarded as such decades ago but now the idea of dichotomy between science and religion has been gradually discarded. The science curriculum which was used in the Malaysian secondary schools until 1974, was heavily influenced by the British curriculum included the evolutionary theory which claimed that living organism originated from simple single cell, and gradually evolved into complex organisms, and human being evolved from apes. The idea that human beings evolved from apes are rejected by the majority of Muslims and that was one of the reasons why science was considered to be opposed to religion. Any society which rejects science will not be able to achieve, while those who reject religion and opt for atheism will lose the important foundation of ethic and morality and ultimately face the 
consequence of moral degradation. The study is thus considered to be important in order to fathom how deep the perception on the relation between science and religion and to take necessary steps to correct the perception if it is proven that the people do have the perception that science is opposed to religion.

\section{Previous Works on Science and Religion}

There are many works on the relation between science and religions. Some regard science and religion are locked at a mortal combat and the battle will rage until one or the other is decimated. The dogmatic scientists such as Atkins (2011) and Dawkins (2006) are some of those scientists who hold the view that religion is a belief without proof and has to be rejected. In the book, Science and Religion: A New Introduction, McGrath (2011) claimed that without naming the Muslim fundamentalists, that science is a threat to their religion. There are many Muslim scientists who accepted the notion that in Islam, science and religion are in harmony with each other. Notably among them are the French physicist, Bruno Guiderdoni, who converted to Islam and was the head of the Paris observatory, commented on the compatibility between science and Islam (Piraino, 2014). Following by Murice Bucaille, Zaglol an-Naggar, Zakir Naik and many others. Hence, Muslim scientists and intellectuals accept that there is strong relation between science and religion. On the other hand the history of science and religion has had a bumpy road along the western history (Richardson, 1995).

Bucaille (1976), the French surgeon wrote the book The Bible, the Quran and Modern Science in which he explicitly claimed that there is no contradiction between the Qur'an and science while there are problems between the Bible and Science. In rejecting the idea that there is no contradiction between the Qur'an and Science, Sardar (1987), without reviewing other scholars of Islam before Bucaille such the 19th century Turkish scholar, Badiuzaman Said Nursi and Abd al-Aziz al-Zindany, labelled the method of proving Qur'an with science as 'Bucaillism'. Sardar (1987) even neglected the verse 53 of sura Fussilat (Explained in detail) in which Allah says:

\section{"We will show them our signs in the horizons and within themselves until it becomes clear to them that it is the truth. But is it not sufficient concerning your Lord that He is, over all things, a Witness?"}

The verse talks about conducting research and observation at the natural world and the make the reference to the Qur'anic verses which will indicate that what the Qur'an says is true. Sardar (1987) claimed that the Qur'an does not need to be validated by science since it is priori true while science is subjected to changes. Earlier scholars of Islam such Fakhr al-Din al-Razi, al-Zarkashi, al-Sayuti, Muhammad Abduh and Tantawi Jauhari had already indulged in the scientific exegesis of the Qur'an (al-tafsir al-ilmiyy). Hoodhboy (1991), in criticizing the proponent of the Quran and science, pinpointed that the late Sheikh Abdul Aziz al-Bazz (1910-1999), the former scholar of Saudi Arabia claimed the sun revolves around the earth which contradicts science. That idea was indeed very rare among the Islamic scholars, leave alone the astronomer Ibn Al-Shatir whose idea of the heliocentricity was adopted by Galileo (Saliba, 1981). The Qur'anic verse which might be referred by Hoodhboy (1991) is in sura Yasin verse 38:

\section{"And the sun runs [on course] toward its stopping point. That is the determination of the Exalted in Might, the Knowing."}

This verse does not indicate whatsoever with the movement of the sun around the earth. It just mentions that the sun floats and moves which is now understood by the scientists as the movement of the sun around the Milky Way. The relationship between science and religion may have some problem on the issue of the theory of evolution which says that human being originated from the apes. The issue should not have been a problem to the Muslim since the proponent of evolution was actually 9th century Muslim scientist Ibn al-Jahiz who promoted the idea of the origin of species as well as the competition between species (Guessoum, 2010). The Qur'an also talks about the evolution of the universe as well as the evolution on living organism where it says:

"Have those who disbelieved not considered that the heavens and the earth were a joined entity, and we separated them and made from water every living thing? Then will they not believe?" (Note 1)

\section{Research Method}

The research was based on questionnaire. 640 respondents were asked to respond to statements which were related to the issues of science and religion. The definition of science in this study is limited to the natural sciences only, not in term of the broader meaning of science which including all type of human knowledge. Moreover, each statement was accompanied with responses 1. Strongly disagree, 2. Disagree, 3 . Not sure, 4. Agree, and 5. Strongly agree. The statements posted to the respondents were related to the relation between science and religion. The statements which were selected for the analysis were question number 15 , and 17 in the questionnaire booklet. Statement 15 was "Science strengthened my belief towards the god" and statement 17 was 
"Both science and religion are important to human being". These statements were selected to be analysed because they were interrelated to each other. The questionnaire which included the two statements were analysed, measure the perception of the respondents toward the issues raised, but they could not tell how much more or less they were. The data were analysed using the SPSS to obtain the descriptive statistics i.e. means, percentages, t-test etc. The findings were interpreted and discussed. The first statement of the questionnaire which was analysed was statement 15 "Science strengthened my belief towards the existence of god".

\section{The Findings}

The first analysis was to obtain the general means for the response of all the respondents. Table 1 shows the mean responses for statement "Science strengthened my belief towards the god"

Table 1. Means response for all respondents

\begin{tabular}{ccccc}
\hline $\mathrm{N}$ & Minimum & Maximum & Mean & Std. Deviation \\
\hline 642 & 1.00 & 5.00 & 3.8224 & 1.13500 \\
\hline
\end{tabular}

Table 1 shows that the mean response for the statement "Science strengthened my belief toward the existence of god". The general mean is 3.8224 that is smaller than 4 (agree) which indicates that the respondents accept the statement but the acceptance is not strong because it lies below 4. Moreover, the data was analysed to obtain the mean response of the respondents according to the religious background. The mean responses are shown in Table 2.

Table 2. Mean responses according to religious background

\begin{tabular}{cccc}
\hline Religion & Mean & $\mathrm{N}$ & Std. Deviation \\
\hline Islam & 4.1923 & 442 & .96733 \\
Christianity & 3.0000 & 59 & 1.06674 \\
Buddhism & 2.9101 & 89 & 1.05141 \\
Hinduism & 3.1667 & 48 & .97486 \\
\hline
\end{tabular}

Table 2 shows the mean responses according to the religious background. The Muslim respondents' mean is 4.1923, the Christian is 3.000, Buddhists is 2.9101 and the Hindus is 3.1667. Table 2 shows that the means responses for the respondents based on religion are different from each other. The Muslims' mean responses for statement 15 is 4.1923 .

The next analysis is to find out whether the difference of means between the respondents' based on their religious background were significant or not. This was done using the t-test. The t-test results are shown in the following table. The first t-test is between the Muslim and the Christian for statement 15 as shown in the following table.

Table 3. T-test between Muslim and Christian

\begin{tabular}{ccccc}
\hline F & Sig. & $\mathrm{t}$ & $\mathrm{df}$ & Sig. (2-tailed) \\
\hline .376 & .540 & 8.783 & 499 & .000 \\
& & 8.150 & 71.318 & .000 \\
\hline
\end{tabular}

Table 3 shows that the difference of mean between the response of the Muslim respondents and the Christian respondents is significant. The significance value (2-tailed) at $95 \%$ confidence limit is 0.000 which is smaller than the critical value of 0.05 and hence the difference of mean is significant. Similarly, t-test was also conducted between the mean response of the Muslim respondents and the Buddhists respondents. 
Table 4. T-test between the Muslim and the Buddhists respondents

\begin{tabular}{ccccc}
\hline $\mathrm{F}$ & Sig. & $\mathrm{t}$ & $\mathrm{df}$ & Sig. (2-tailed) \\
\hline .343 & .559 & 11.240 & 529 & .000 \\
\hline
\end{tabular}

Table 4 shows that there is a significant different between the mean response of the Muslim respondents and the Buddhists respondents. The significance value ( 2 tailed) and the $95 \%$ confidence limit is 0.000 which is smaller than the critical value of 0.05 . The difference of mean between the Muslim and the Buddhist respondents is significant. As a further matter, the next t-test is between the Muslim respondents and the Hindu respondents. The result of the analysis is shown in Table 5.

Table 5. T-test between the Muslim respondents and the Hindu respondents

\begin{tabular}{ccccc}
\hline $\mathrm{F}$ & Sig. & $\mathrm{t}$ & $\mathrm{df}$ & Sig. (2-tailed) \\
\hline .470 & .493 & 6.972 & 488 & .000 \\
& & 6.928 & 57.518 & .000 \\
\hline
\end{tabular}

Table 5 shows there is significant different between the mean response of the Muslim and the mean response of the Hindu respondents. The significance value (2-tailed) is 0.000 at the $95 \%$ confidence level which is smaller than 0.05 . This indicates that the mean difference is significant. Besides it, the next $t$-test is for the statement between the Christian and the Hindu respondents. The result of the t-test is shown in table 6 .

Table 6. T-test between the Christian and the Hindu respondents

\begin{tabular}{ccccc}
\hline $\mathrm{F}$ & Sig. & $\mathrm{t}$ & $\mathrm{df}$ & Sig. (2-tailed) \\
\hline .725 & .397 & -.835 & 105 & .406 \\
& & -.843 & 103.546 & .401 \\
\hline
\end{tabular}

Table 6 shows that the difference of mean between the responses of the Christian respondents and the Hindu respondents is not significant. The significance value is 0.406 and 0.401 and the values are greater that the critical value of 0.05 . Therefore, the mean difference between the mean of the Christian respondents and the Hindu respondents is not significant. T-test between the different religious groups is not conducted for the statement number 17, since the mean responses are very close to each other except for the mean of the Muslim respondents. The t-test will give the same results. The data was also analysed to obtain the percentage of the responses in general as well as according to the religious groups. The result of the analysis is shown in Table 7.

Table 7. Percentages of the responses

\begin{tabular}{ccccc}
\hline & Frequency & Percent & Valid Percent & Cumulative Percent \\
\hline Strongly disagree & 20 & 1.6 & 3.1 & 3.1 \\
Disagree & 75 & 5.8 & 11.7 & 14.8 \\
Not sure & 135 & 10.5 & 21.0 & 35.8 \\
Agree & 181 & 14.0 & 28.2 & 64.0 \\
Strongly agree & 231 & 17.9 & 36.0 & 100.0 \\
\hline
\end{tabular}

Table 7 shows that the percentages of the respondents who reject the statement were $14.8 \%$ (cumulative percentage), those who were not sure were $21.0 \%$ and those who accepted the statement were $64.2 \%$. The percentages of the responses were plotted to form a bar chart as shown in Figure 1. 


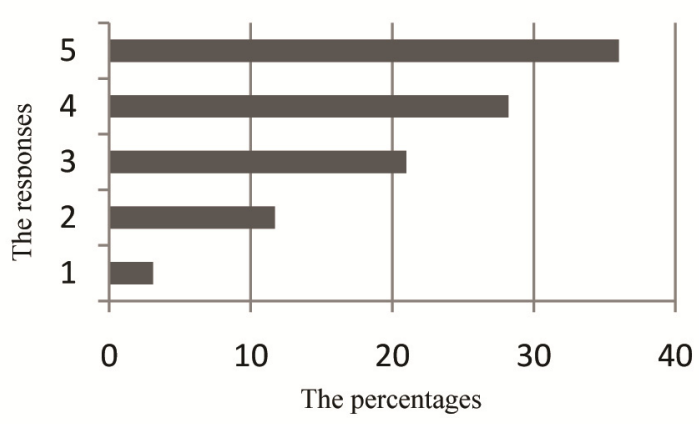

Figure 1. Bar chart percentage of the responses

Figure 1 shows that the response for the statement 15, "Science strengthened my belief towards the existence of god" increases from 1. Strongly disagree to 5. Strongly agree. Furthermore, the percentages of the responses based on religions are shown in the following Table 8.

Table 8 . The percentages of the mean responses based on religion

\begin{tabular}{ccccccccc}
\hline & \multicolumn{2}{c}{ Muslim } & \multicolumn{2}{c}{ Christian } & \multicolumn{2}{c}{ Buddhist } & \multicolumn{2}{c}{ Hindu } \\
\hline Strongly disagree & 3 & 0.7 & 2 & 3.4 & 10 & 11.2 & 4 & 8.3 \\
Disagree & 29 & 6.6 & 21 & 35.6 & 20 & 22.5 & 5 & 0.4 \\
Not sure & 67 & 15.2 & 17 & 28.8 & 30 & 30.7 & 20 & 1.7 \\
Agree & 124 & 28.1 & 13 & 22.0 & 26 & 29.2 & 17 & 35.4 \\
Strongly agree & 219 & 49.5 & 6 & 0.2 & 3 & 3.4 & 2 & 4.2 \\
\hline
\end{tabular}

Table 8 shows the responses to the statement "Science strengthened my belief toward the existence of god" in which $77.6 \%$ of the Muslim respondent accepted, $32.2 \%$ of the Christian respondent accepted. $33.6 \%$ of the Buddhists respondent accepted and $49.6 \%$ of the Hindu respondents accepted. The percentages of the responses according to the religious background are plotted into line graph as shown in Figure 2.

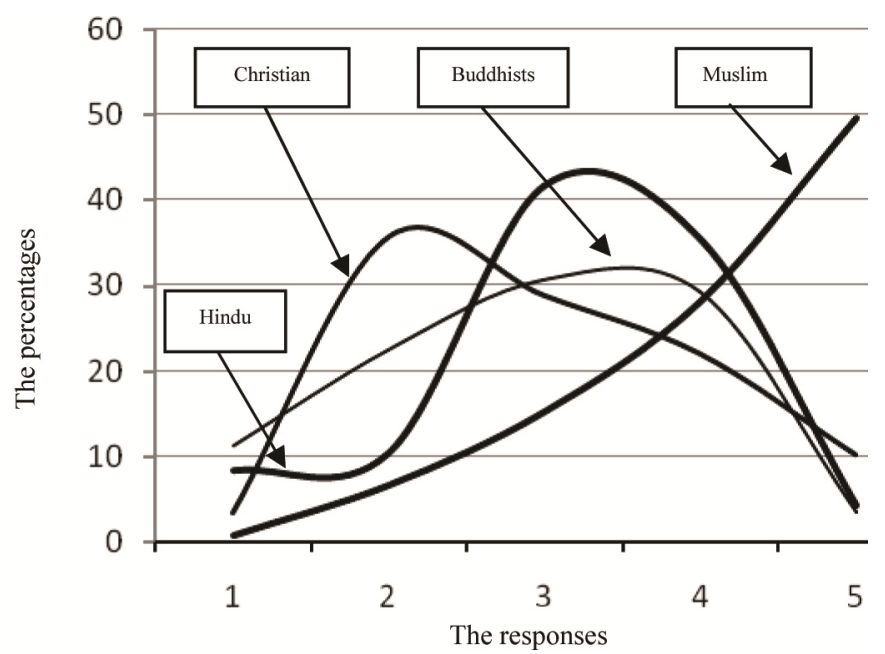

Figure 2. The percentages of the responses according to religious background

Figure 2 shows the difference line graph of the percentages of responses for the different religious groups. The 
line graph shows clearly that the responses of the Muslim respondents progressively increases with the scale of the responses, the responses of the other religious groups seem to be slightly in a normal curve. In addition, the analysis was also conducted on the data for the statement number 17 which specifically touches the importance of science and religion. Statement 17 is "Both science and religion are important for human progress". The mean response is shown in Table 9.

Table 9. Mean response for statement 17

\begin{tabular}{ccccc}
\hline $\mathrm{N}$ & Minimum & Maximum & Mean & Std. Deviation \\
\hline 644 & 1.00 & 5.00 & 4.1693 & .92196 \\
\hline
\end{tabular}

Table 9 shows that generally the respondents accept the statement "Science and religion are important for human progress". The mean response is 4.1693 which lies between 4 (agree) and 5 (strongly agree). The data was also analysed to obtain the mean response of the respondents from different religious background.

Table 10. Mean response according to religious background

\begin{tabular}{cccc}
\hline Religion & Mean & $\mathrm{N}$ & Std. Deviation \\
\hline Islam & 4.3386 & 443 & .85248 \\
Christianity & 3.6780 & 59 & .95485 \\
Buddhism & 3.8222 & 90 & .96661 \\
Hinduism & 3.8333 & 48 & .97486 \\
\hline
\end{tabular}

Table 10 shows the mean responses for statement "Both science and religion are important for human progress". The mean response for the Muslim respondent is 4.3386, Christian is 3.6780, the Buddhists is 3.8222 and the Hindus is 3.8333 .

\section{Discussion}

The results of the study show that in general the respondents accepted that science could strengthen the belief toward the existence of God, that science could explain the greatness of God and science and religion could benefit the people. The means responses are greater than the neutral value 3. The finding is in line with the result of the data analysis to obtain the percentages of the responses in general. Figure 1 shows that the majority of the respondents $(64.2 \%)$ accepted the statement. However, when the data was analysed according to the religious background of the respondents, the findings show that there were difference of mean values for all the four religions i.e. Islam, Christianity, Buddhism and Hinduism and the difference of means between the Muslim respondents and the other religious groups are significant but the difference of mean between the mean responses of the respondents of other religious groups are not significant. This implies that the difference of mean response between the Muslim respondents and the other religious groups is real and significant.

The difference of perception between the different religious groups could be seen clearly from the line graph plotted from the percentages of the response shown in figure 2. The responses of the non-Muslim respondents i.e. Christian, Buddhists and the Hindus seem to be close to normal curve shape, implying that most of the respondents were closer to uncertain with the statement "Science could strengthened my belief toward the existence of God" while the responses of the Muslim respondents progressively increases from strongly disagree with the statement to strongly agree with the statement. This indicates that the Muslim respondents are comfortably confident that science could bring them closer to God. The finding may reflects the real issue of the relation between religions and science inherent to religions.

Islam regards the study of nature is part and parcel of the religion itself. The Islamic tenet of faith i.e. the acceptance of the existence of Allah is proven by studying the universe which is regarded by Islam as the signs of Allah. The Qur'an itself which is considered by the Muslim to be the words of Allah contains more than 1000 verses out of the 6236 verses in which the nature of the universe is described. The Qur'an extols the believers to study the universe; among the verses which encourage the people to study the universe are al-Baqarah (The Cow) verse 164, al-Nahl (The Bee) verse 79, al-Ghashiah (The Overwhelming) verses17, 18 and19, and many others. 
The relationship between the Quran and science leads to the way how Muslims regard science and there has never been any problem between Islam and science. In the western world, there had been difficulties between science, scientists and religion. White (1896) argued that the Christian theologians had a long history of opposing science in the interest of dogmatic theology. Although White's argument is rejected by Ferngren (2013), it is well known historical fact that Galileo Galilei, the Italian astronomer was incarcerated because of his opinion that the universe was heliocentric rather than geocentric (Rowland, 2001). The incident reflects the difficult relationship between science and religion in Christianity. The difficult relationship between religion and science is manifested in the dwindling number of the believers in the western society.

In connection with this, Euro barometer poll 2010, which claimed that the belief in the existence of god is less that $18 \%$ in the Republic of Czech, Estonia and Sweden, between 20 to 30\% in Norway, France, Netherland, between 30 to $40 \%$ in Iceland, Slovenia, Finland, Bulgaria, United Kingdom, Belgium and Latvia, between 41 to $50 \%$ in Austria, Germany, Switzerland, Luxemburg and Lithuania. Turkey which is considered to be the European Union candidate was included in the poll. The poll discovered that Turkey which is overwhelmingly Muslim country show that $94 \%$ of the population believe in the existence of God (Kiviorg, 2011).

Many proponents of religious belief claimed that religion is the basis of ethic and morality (Nielson, 1991) and Broom (2003).Therefore, if the assertion is true, then as religious belief weakened, the moral system also weakened. It goes in tandem with the rejection of religious belief due to scientific progress.

The western countries in generals are known to practice good governance, transparency, democratic and other humanistic values which are rarely seen in the third world countries including the Muslim majority countries (Transparency International: CPI, 2012) Despite that the Western countries and other developed countries are facing three main problems i.e. lost of trust, crime and population decline which is caused by individualism (Fukuyama, 2000). The economically advanced western countries are facing population decline because of the sex revolution which rejected the traditional family values. In the name of freedom, almost all of the European Union members, as well as most of the states in the United States of America, Australia and New Zealand have allowed the same sex marriage. Probably in the words of Toynbee (1988), the Western Civilisation will decline because of the rejection of the Christian religion.

The study shows that Malaysian, especially the Muslims seem to maintain their belief in the existence of god and the belief in religion. The strength of the belief may save them from the moral decline as in the western civilisation.

\section{References}

Atkins, P. (2011). On Being: A Scientist's Exploration of the Great Questions of Existence. Oxford: Oxford University Press.

Bucaille, M. (1976). The Bible, the Quran and Science. Indianapolis: American Trust Publication.

Broom, D. M. (2003). The Evolution of Morality and Religion. Cambridge: Cambridge University Press. http://dx.doi.org/10.1017/CBO9780511610226

Dawkins, R. (2006). The God Delusion. Boston: Houghton Mifflin Co.

Faruqi, I. R. (1992). Al Tawid: Its Implications for Thought and Life. Kuala Lumpur: International Institute of Islamic Thought.

Ferngren, G. B. (2013). Science and Religion: A Historical Introduction. Baltimore, Maryland: JHU Press.

Fukuyama, F. (2000). The Great Disruption: Human Nature and the Reconstitution of Social Order. Free Press.

Garaudy, R. (1982). Janji-janji Islam [The Promise of Islam]. Jakarta: Bulan Bintang.

Guessoum, N. (2010). Islam's Quantum Question: Reconciling Muslim Tradition and Modern Science. London: Tauris \& Co.

Hoodhboy, P. (1991). Islam and Science: Religious Orthodoxy and the Battle for Rationality. New Jersey: Zed Books.

Kiviorg, M. (2011). Estonia. In R. Toefs (Ed.), International Encyclopaedia of Law: Religion. USA: Kluwer Law International.

McGrath, A. (2011). Science and Religion: An Introduction. UK: Wiley-Blackwell.

Moravcsick, M. J. (1988). On the Road to Worldwide Science: Contributions to Science Development. New Jersey, USA: World Scientific. 
Nielson, K. (1991). God and the Grounding of Morality. Ottawa: University of Ottawa Press.

Piraino, F. (2014). Bruno Guiderdoni Among Sufism, Traditionalism and Science: A Reply to Bigliardi. Social Epistemology Review and Reply Collective, 3(11), 21-24.

Richardson, M. (2005). Faith in Science: Scientists Search for Truth. London: Routledge.

Rowland, W. (2001). Galileo's Mistake. New York: Archade Publishing Inc.

Sardar, Z. (1987). The Future of Muslim Civilisation. London: Cromwell.

Saliba, G. (1981). Science and Religion: A Historical Introduction. Journal for the History of Astronomy, 18(1), 35.

Toynbee, A. (1988). A Study of History. Oxford: Oxford University Press.

White, A. D. (1896). A History of the Warfare of Science with Theology in Christendom. New York: Appelton.

\section{Note}

Note 1. See Qur'an, Chapter Al-Anbiya' (The Prophets) verse 30.

\section{Copyrights}

Copyright for this article is retained by the author(s), with first publication rights granted to the journal.

This is an open-access article distributed under the terms and conditions of the Creative Commons Attribution license (http://creativecommons.org/licenses/by/3.0/). 